\title{
APPLICATION OF DEGRADABLE CARBON AND NITROGEN MODERATES CARBON SEQUESTRATION POTENTIAL OF BIOCHAR IN ARABLE SOILS
}

\author{
VLADIMÍR ŠIMANSKÝ $\otimes^{1}$, JÁN HORÁK², MARTIN LUKÁČ ${ }^{3}$ \\ ${ }^{1}$ Department of Soil Science, Faculty of Agrobiology and Food Resources, Slovak University of Agriculture, Tr. A. Hlinku 2, 94976 Nitra, Slovak Republic; \\ e-mail: Vladimir.Simansky@uniag.sk \\ ${ }^{2}$ Department of Biometeorology and Hydrology, Slovak University of Agriculture, Nitra, Slovak Republic \\ ${ }^{3}$ School of Agriculture, Policy and Development, University of Reading, Reading, United Kingdom \\ $\square$ Corresponding author
}

Received: 29 April 2020 / Accepted: 21 August 2020

\begin{abstract}
Šimanský V., Horák J., Lukáč M.: Application of degradable carbon and nitrogen moderates carbon sequestration potential of biochar in arable soils. Ekológia (Bratislava), Vol. 40, No. 2, p. 124-129, 2021.

Biochar can affect $\mathrm{CO}_{2}$ emission and $\mathrm{C}$ sequestration from soils, but little is known about the effects of its re-application and interaction with easily accessible substrates. Since most agricultural soils are continuously reworked, understanding the mechanics of $\mathrm{CO}_{2}$ evolution as affected by soil amendments and their combinations may have important lessons for the global effort to combat climate change. In this study carried out in a controlled environment, we tested the short-term effects of biochar, and its re-application at different rates, on the production of $\mathrm{CO}_{2}$ emission and $\mathrm{C}$ accumulation in samples of arable soils. We used a loamy Haplic Luvisol as the substrate and added varying amounts of biochar and sources of easily accessible $\mathrm{N}$ and $\mathrm{C}$. We observed $\mathrm{CO}_{2}$ evolution for 20 days at optimal temperature and moisture conditions. We found that in the control treatment with no biochar, the total potential respiration after the addition of $\left(\mathrm{NH}_{4}\right)_{2} \mathrm{SO}_{4}(\mathrm{~N})$ and glucose $(\mathrm{G})$ was increased compared to basal respiration. The addition of biochar reduced $\mathrm{CO}_{2}$ emission in the control, N- and G-stimulated treatments by 12-22, 13-24 and 2-21\%, respectively. Conversely, the application of biochar increased $\mathrm{CO}_{2}$ emission in the combined NG treatment. Application of biochar at a higher rate, as well as its re-application, increased soil organic carbon content and reduced emission of $\mathrm{CO}_{2}$ into the atmosphere.
\end{abstract}

Key words: basal and substrate-induced respiration, carbon sequestration, biochar.

\section{Introduction}

Agriculture, natural resource management and food security are inseparable facets of the human development and climate change challenges of the twenty-first century (Šikanja, Milovanovic, 2020). Agriculture is a contributor to and is affected by climate and environmental changes. Large-scale expansion and intensification of agricultural activities, driven by expanding human population and rising incomes, have contributed significantly to both land degradation and greenhouse gas emission (GHG) (Biswas et al., 2019). According to recent data (IPCC, 2018), global emission of GHGs was about 40 gigaton carbon dioxide equivalent, out of which about $11 \%$ is generated by agriculture through emission from soils, nutrient management and livestock husbandry. Currently, there is considerable political and social interest across the globe to reduce GHGs emission from crop production systems. Nitrous oxide, carbon dioxide and methane are released to the atmosphere through processes including microbial decay of soil organic matter and microbial transformation of N (Smith et al., 2014). Although these processes occur naturally and are part of normal soil development and function, their contribution to GHG emission is enhanced by modern agricultural practices.

A significant research effort is being invested into the development of practices and interventions that would allow for concurrent food production and a reduction of GHGs from agriculture. One such measure that carries the promise of reducing $\mathrm{CO}_{2}$ emission from the soil is the application of biochar to arable soils. Biochar is the product of organic biomass conversion at a high temperature with low or no oxygen availability, which results in a low-decomposability product rich in $\mathrm{C}$ with the potential to sequester $\mathrm{C}$ in the long term. The addition of biochar to soils has been suggested as a strategy to increase soil carbon storage; however, the stability of biochar is fundamental to its function as a long-term option. Several recent studies indicate that biochar can also affect the stability of native soil organic carbon (SOC) pool, i.e., it may induce a positive or negative priming effect (Whitman et al., 2015; Cheng et al., 2016).

Soil respiration is a very important parameter indicative of soil function and is affected by nearly all agriculture practices (Popelárová et al., 2002). Tests of soil respiration are frequently used for the evaluation of soil biological activity. It can be also 


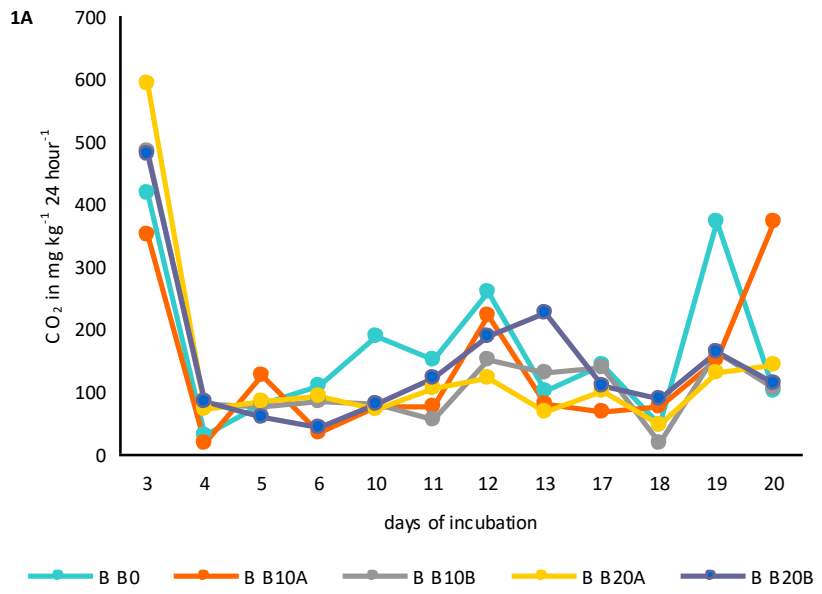

$1 \mathrm{C}$

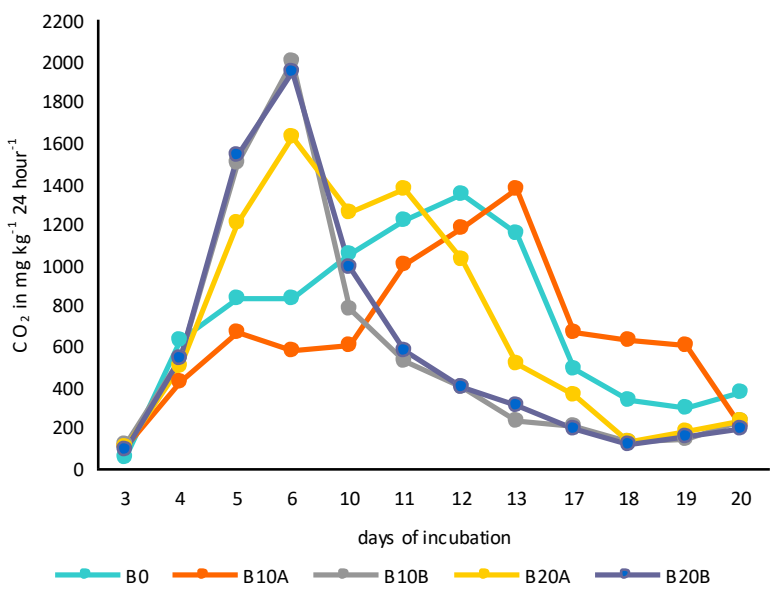

$1 \mathrm{~B}$

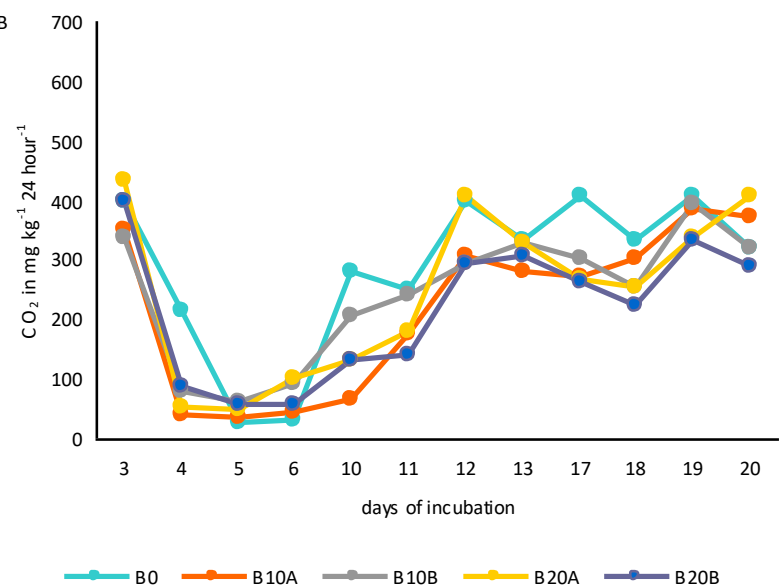

1D

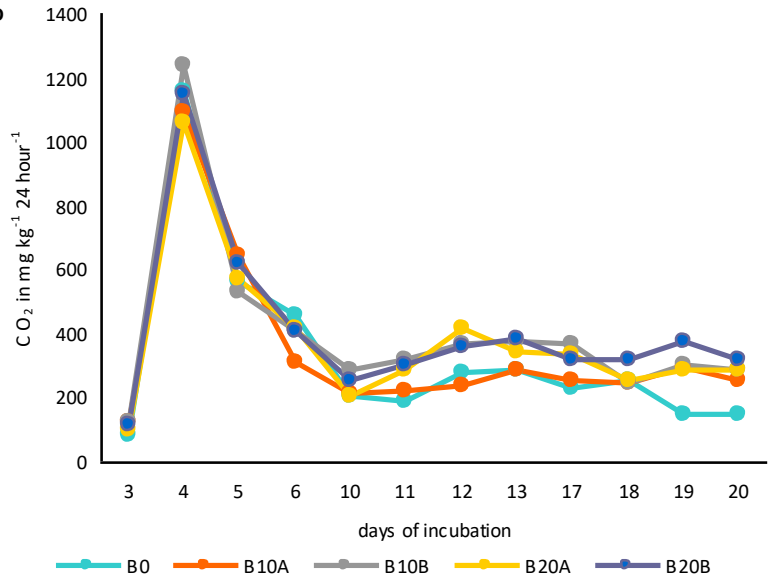

Fig. 1. Emission of $\mathrm{CO}_{2}$ (daily - during experiment) produced by A) basal, B) N-induced, C) G-induced, and D) NG-induced respiration in all treatments.

used for assessing the speed of mineralization of organic substances present or added to the soil. In this respect, basal respiration is defined as the respiration of organic compounds present in the soil. Source-induced respiration is then defined as the flux of $\mathrm{CO}_{2}$ from the soil after addition of substances normally limiting respiration, commonly either $\mathrm{C}$ - or $\mathrm{N}$-containing substrates (Alef, Nannipieri, 1995). Adding these substances often mimics the effects of common soil management practices of farmers, such as mineral $\mathrm{N}$-fertilization or crop residue incorporation.

Changes in agricultural soil respiration rate clearly have a detectable impact on the atmospheric $\mathrm{CO}_{2}$ concentration (Schlesinger, Andrews, 2000); however, we still lack a detailed understanding of the effects of interventions on GHG emission. For example, the impacts of biochar, its re-application to soils and its interaction with nitrogen and easily degradable organic substances did not receive much attention to date. To bridge this gap, the objectives of this study were to (i) evaluate the impacts of different rates of biochar and its re-application on $\mathrm{CO}_{2}$ emission produced by basal respiration; (ii) to describe the potential peak respiration as induced by adding nitrogen and glucose; (iii) to quantify the effect of biochar addition on soil organic carbon and its labile forms; and (iv) to determine the relationship between soil organic carbon content and emission of $\mathrm{CO}_{2}$ in relation to biochar application.

\section{Material and methods}

Representative soil samples of a loamy Haplic Luvisol were taken from individual biochar treatments (field experiment established in 2014) from the A-horizon in Autumn 2018. After drying, homogenization and stabilization at $4{ }^{\circ} \mathrm{C}$ in the fridge for 4 weeks, the soil samples were used to set up a short-term laboratory experiment. Small, 0.22 litre containers were used to carry out an incubation study over 20 days. The laboratory experiment included the following five treatments, each replicated three times: (1) B0 - no addition of materials; (2) B10A - biochar at the rate of $10 \mathrm{t} \mathrm{ha}^{-1}$ (treatment with $10 \mathrm{t} \mathrm{ha}^{-1}$ biochar applied in 2014); (3) $\mathrm{B} 10 \mathrm{~B}$ - re-applied biochar at the rate of $10 \mathrm{tha}^{-1}$ (treatment with $10 \mathrm{t} \mathrm{ha}^{-1}$ biochar applied in 2014 and re-applied in 2018 at the same rate); (4) $\mathrm{B} 20 \mathrm{~A}$ - biochar at the rate of $20 \mathrm{t} \mathrm{ha}^{-1}$ (treatment with $20 \mathrm{t} \mathrm{ha}^{-1}$ biochar applied in 2014); and (5) B20B - reapplied biochar at the rate of $20 \mathrm{t} \mathrm{ha}^{-1}$ (treatment with $20 \mathrm{t} \mathrm{ha}^{-1}$ biochar applied in 2014 and re-applied in 2018 at the same rate). All samples were normalized to $200 \mathrm{~g}$ per container prior to sealing. The biochar was produced by pyrolyzing paper fibre sludge and grain husks (1:1 w/w) (company Sonnenerde, Austria). Biomass was pyrolyzed at $550{ }^{\circ} \mathrm{C}$ for 30 minutes in a Pyreg reactor (Pyreg GmbH, Dörth, Germany). The result was a product with the particle size of $1-5 \mathrm{~mm}$. On average, it contained $57 \mathrm{~g} \mathrm{~kg}^{-1}$ of 


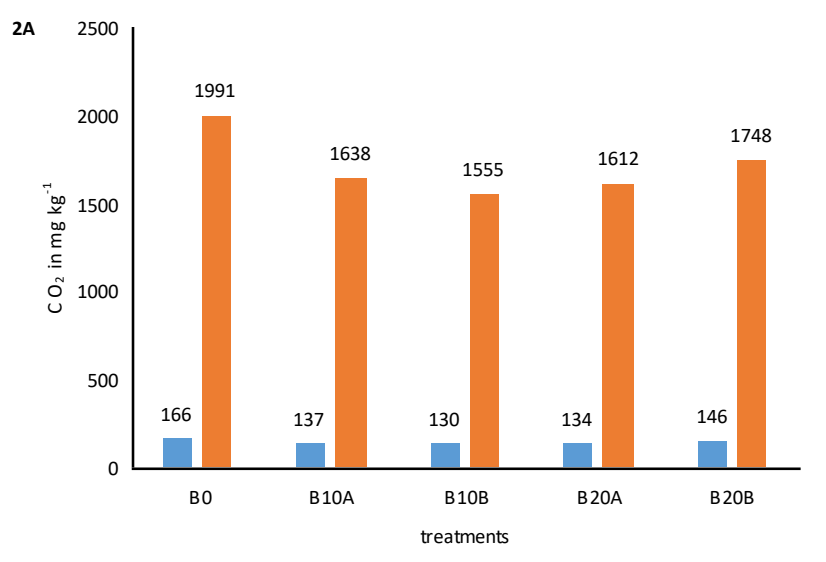

- averag e daily emissions $\quad$ c cumulative emissions

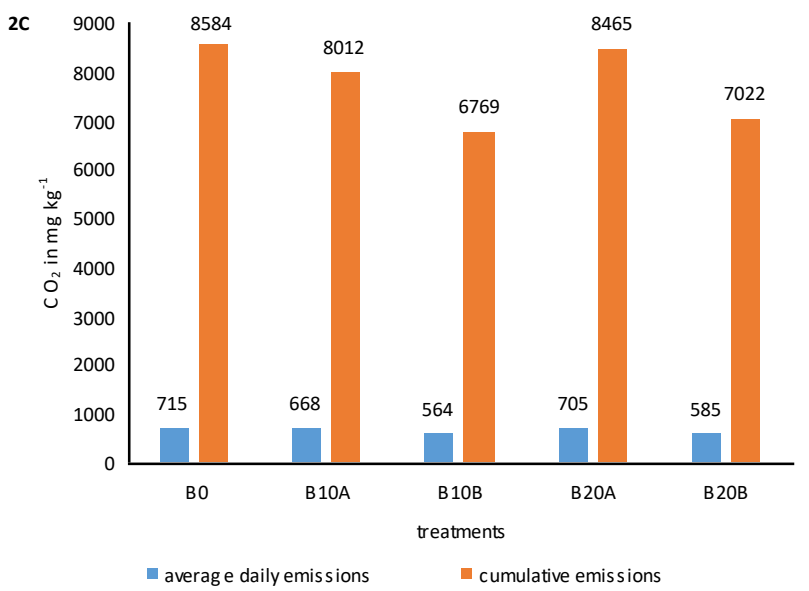

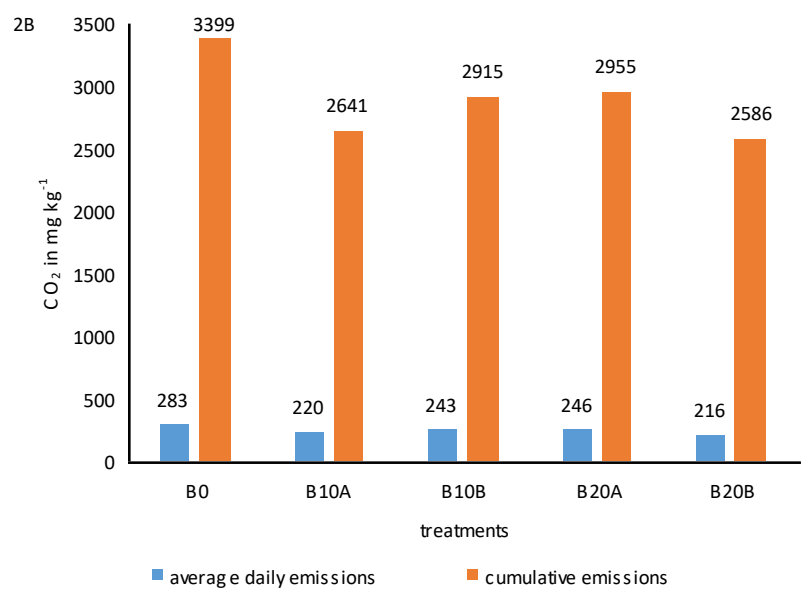

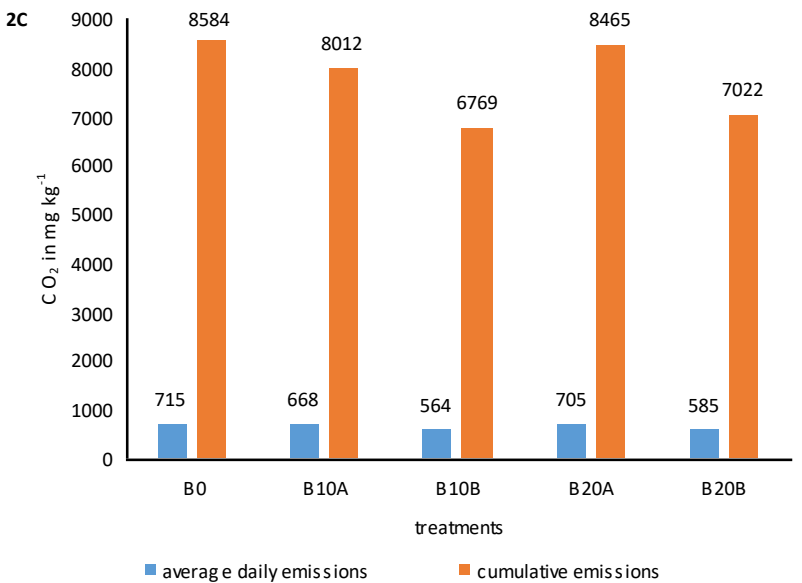

Fig 2. Average daily and cumulative emission of $\mathrm{CO}_{2}$ produced by A) basal, B) N-induced, C) G-induced, and D) NG-induced respiration in all treatments.

$\mathrm{Ca}, 3.9 \mathrm{~g} \mathrm{~kg}^{-1}$ of $\mathrm{Mg}, 15 \mathrm{~g} \mathrm{~kg}^{-1}$ of $\mathrm{K}$ and $0.77 \mathrm{~g} \mathrm{~kg}^{-1}$ of Na. The total C content of biochar was $53.1 \%$, while total $\mathrm{N}$ content was $1.4 \%$, the C:N ratio was 37.9 , the specific surface area was $21.7 \mathrm{~m}^{2} \mathrm{~g}^{-1}$, and the content of ash was $38.3 \%$. On average, the biochar $\mathrm{pH}$ was 8.8 . During incubation, optimal temperature $\left(23-25^{\circ} \mathrm{C}\right)$ and moisture (50-60\% of the field water capacity) were maintained.

Basal and potential soil respiration was measured 16 times during an experiment by the absorption method (Duiker, Lal, 1999). Basal respiration was initiated by adding $2 \mathrm{~mL}$ of distilled water to all treatments. We then measured basal respiration and proceeded to the determination of the potential respiration by adding $\left(\mathrm{NH}_{4}\right)_{2} \mathrm{SO}_{4}$ (at the rate of $2 \mathrm{~mL}$ in $25 \%$ concentration) and glucose (at the rate of $2 \mathrm{~mL}$ in $25 \%$ concentration) separately and in combination (at the rate of $2: 1 \mathrm{~mL}$ of $50 \%\left(\mathrm{NH}_{4}\right)_{2} \mathrm{SO}_{4}$ and 1 $\mathrm{mL}$ of $50 \%$ glucose). After the incubation period, all soil samples were dried and combined into a single sample per treatment. The composite samples were analysed for soil organic carbon content $\left(\mathrm{C}_{\text {org }}\right)$ by the wet combustion method that is the oxidation of organic matter by a mixture of $\mathrm{H}_{2} \mathrm{SO}_{4}$ and $\mathrm{K}_{2} \mathrm{Cr}_{2} \mathrm{O}_{7}$ with titration using Mohr's salt (Dziadowiec, Gonet, 1999). In addition, the labile carbon content $\left(\mathrm{C}_{\mathrm{L}}\right)$ was determined using $0.005 \mathrm{~mol} \mathrm{dm}^{-3}$ $\mathrm{KMnO}_{4}$ (Loginow et al., 1987), and hot-water extracted carbon $\left(\mathrm{C}_{\mathrm{HWD}}\right)$ was determined according to the method of Körschner et al. (1990).
The data were analysed using one-way ANOVA and the means (average values of soil parameters over the whole studied period) were compared using the LSD test at $p<0.05$. The correlation matrix was used to study the relationship between the SOM and $\mathrm{CO}_{2}$ emission. All data were analysed using the Statgraphics Centurion XV.I programme (Statpoint Technologies, Inc., USA).

\section{Results and discussion}

\section{Basal respiration}

The highest $\mathrm{CO}_{2}$ emission rate was measured shortly after initiating the basal respiration, a phase that lasted about 3 days of incubation in all treatments. The treatment with $10 \mathrm{t} \mathrm{ha}^{-1}$ of biochar had significantly lower $\mathrm{CO}_{2}$ emission compared to the no-additional reference soil. Conversely, soils with the re-application of 10 and $20 \mathrm{t} \mathrm{ha}^{-1}$ of biochar showed higher $\mathrm{CO}_{2}$ emission than the reference at the initial stage of incubation. Initially, we observed very intensive $\mathrm{CO}_{2}$ production, but by the fourth day of incubation, there was an almost three- to four-fold decrease in basal respiration in all treatments. Subsequently, basal respiration increased gradually until day $11-13$ of incubation (Fig. 
1A). Overall, daily average $\mathrm{CO}_{2}$ emissions over the 20 days of the experiment in $\mathrm{B} 0, \mathrm{~B} 10 \mathrm{~A}, \mathrm{~B} 10 \mathrm{~B}, \mathrm{~B} 20 \mathrm{~A}$ and $\mathrm{B} 20 \mathrm{~B}$ were 166,137 , 130,134 and $146 \mathrm{mg} \mathrm{CO}_{2} \mathrm{~kg}^{-1}$ of soil ${ }^{-1}$, respectively. Compared to the $\mathrm{B} 0$ treatment, total cumulative $\mathrm{CO}_{2}$ emissions over the whole incubation experiment ( 20 days) were significantly lower by 18 , 22,19 and $12 \%$ in the $\mathrm{B} 10 \mathrm{~A}, \mathrm{~B} 10 \mathrm{~B}, \mathrm{~B} 20 \mathrm{~A}$ and $\mathrm{B} 20 \mathrm{~B}$ treatments, respectively (Fig. 2A). Previous studies have shown that there are regular fluctuations in soil respiration and that these changes are affected by temperature (Lang et al., 2017) and soil moisture (Horák et al., 2020). Our observations originate from controlled and optimal conditions, so any fluctuations due to changes in soil moisture or temperature on $\mathrm{CO}_{2}$ emission are thus removed. These factors play an important role in field conditions, as reported by Horák et al. (2017), but often confound the more subtle effects of soil organic matter composition or nutrient availability. The application and especially re-application of the biochar played an important role in driving basal respiration and $\mathrm{CO}_{2}$ emission in our controlled conditions.

\section{Source-induced respiration}

Reference treatment (B0) showed that total potential respiration (after addition of nitrogen and glucose) as indicated by $\mathrm{CO}_{2}$ emission significantly higher than basal respiration. $\mathrm{CO}_{2}$ emission produced by $\mathrm{N}$-induced respiration was highest in all treatments during the initial day of incubation (day 3), but $\mathrm{CO}_{2}$ emission subsequently dropped significantly during the following three days (days 4, 5 and 6) as shown Figure 1B. Over the next days, $\mathrm{N}$-induced $\mathrm{CO}_{2}$ emission gradually increased almost to the values measured at the start of the incubation. However, it should be pointed out that the cumulative $\mathrm{CO}_{2}$ emissions induced by $\mathrm{N}$ were $22,14,13$ and $24 \%$ lower in the B10A, B10B, $\mathrm{B} 20 \mathrm{~A}$ and $\mathrm{B} 20 \mathrm{~B}$ compared to the reference B0 treatment (Fig. 2B). This means that the addition of $\mathrm{N}$ did not increase the $\mathrm{CO}_{2}$ emission as expected, leading to a decrease in total emission in this treatment. Interestingly, the lowest average daily $\mathrm{N}$-induced $\mathrm{CO}_{2}$ emission was observed in treatments with higher re-application of biochar dose over the whole incubation period. Biochar application can influence $\mathrm{N}$ cycling (e.g. $\mathrm{N}$ mineralization, nitrification, and denitrification) via regulating soil microbial activity (Wang et al., 2015), thereby altering the emission of GHGs (He et al., 2017).

One of the objectives of this study was to investigate the interactive effect of biochar and an easily decomposable substrate on soil $\mathrm{CO}_{2}$ emission. We applied glucose $(\mathrm{G})$ as a source of easily accessible energy for the microorganisms at the beginning of the experiment. Our results show that peak G-induced $\mathrm{CO}_{2}$ emission was not found at the start of the incubation (after 3 days of incubation) as expected but occurred between 6 and 19 days after the start of the incubation, and the timing of the peak was af fected by biochar addition. Re-application of biochar to the soil, especially at a higher rate, shows a more pronounced effect on G-induced $\mathrm{CO}_{2}$ emission compared to control up to 6 days of incubation. Over the next period, G-induced $\mathrm{CO}_{2}$ emission in biochar treatments decreased significantly compared to B0 (Fig. 1C). The average daily $\mathrm{CO}_{2}$ emission induced by the addition of easily degradable $\mathrm{C}$ was the highest in $\mathrm{B} 0$ and significantly lower in both biochar treatments applied in 2014, as well as those re-applied in 2018 (Fig. 2C). The cumulative $\mathrm{CO}_{2}$ emission was also lowered by biochar addition, significantly more so in treatments with biochar re-application. Our results are consistent with those of Rizhiya et al. (2020), where the cumulative $\mathrm{CO}_{2}$ emission from organic amendments (biochar and compost) was generally lower than those containing mineral fertiliser. In our case, this result (reduction of G-induced $\mathrm{CO}_{2}$ emission) could indicative of mechanisms through which biochar interferes with SOC mineralization, especially through the sorption of labile carbon (Whitman et al., 2015). Biochar has demonstrated a high sorption affinity for a wide range of natural organic compounds including recalcitrant organic matter (Kasozi et al., 2010) and labile and water-soluble fractions of soil organic matter (SOM), making them less available microbes. This may take the form of encapsulation where SOM is absorbed within pores in biochar particles and becomes physically unavailable to microbes (Whitman et al., 2015).

The $\mathrm{CO}_{2}$ emission timeline induced by NG together was substantially different from basal respiration emission or those induced by nitrogen and glucose individually. The highest daily mean $\mathrm{CO}_{2}$ emission in all treatments was found after 4 days after the start of incubation and then subsequently decreased. However, $\mathrm{CO}_{2}$ emission decreased significantly slower than in the $\mathrm{B} 0$ treatment in biochar treatments (Fig. 1D). Overall, the mean daily $\mathrm{CO}_{2}$ emissions induced by the NG treatment were the highest in the B20 treatment, increasing still further after the re-application of biochar in $\mathrm{B} 20 \mathrm{~B}$. The cumulative $\mathrm{CO}_{2}$ emission over the whole incubation period in $\mathrm{B} 10 \mathrm{~A}, \mathrm{~B} 10 \mathrm{~B}, \mathrm{~B} 20 \mathrm{~A}$ and B20B treatments was increased by $4,21,14$ and $23 \%$, respectively, in comparison to B0 (Fig. 2D). Rizhiya et al. (2020) posit that a mixture of biochar, nitrogen and compost had $10 \%$ higher cumulative $\mathrm{CO}_{2}$ emission from soils compared to pure biocharamended soils. It is in line with several other studies reporting the synergistic effects of nitrogen fertilization and biochar (Asai et al., 2011; Schulz et al., 2012).

\section{Evaluation of soil organic carbon content and its labile forms}

Biochar is representing a carbon-based material (Fisher, Glaser, 2012), and its carbon content depends on its production process and feedstock properties (Ippolito et al., 2015). Since biochar used in our study contained $53.1 \%$ of carbon and it is thought to represent a stable organic carbon compound, we anticipated that most of the carbon added to the soils in 2014 and during the reapplication in 2018 would find its way to the stable soil organic matter pool. It is evident from our results (Table 1) that the application of biochar at the higher rate, as well as the re-application at both rates, had a significant and positive effect on the $\mathrm{C}_{\text {org }}$ contents in the soil. Alongside the abovementioned factors affecting the stability of biochar, its ageing may influence carbon retention in the soil. This is linked with the length of contact of biochar particles with soil particles and the changes of labile $\mathrm{C}$ in the soil after biochar application (Šimanský et al., 2016). The labile carbon $\left(C_{L}\right)$ content significantly increased only in B20A treatment as a result of the initial application of biochar at a higher rate. The content of hot-water extracted carbon $\left(\mathrm{C}_{\mathrm{HWD}}\right)$, representative of the most labile form $\mathrm{C}_{\text {org }}$, did not change significantly as a result of biochar application, indicating the relative stability of biochar used in our experiment. The content of $\mathrm{C}_{\text {org }}$ and its forms did not 
Table 1. Contents of $\mathrm{C}_{\text {org }}, \mathrm{C}_{\mathrm{L}}$ and $\mathrm{C}_{\mathrm{HWD}}$ after the experiment - in all treatments

\begin{tabular}{|l|c|c|c|}
\hline \multirow{2}{*}{ Treatments } & $\mathbf{C}_{\text {org }}$ & C $_{\mathbf{L}}$ & C $_{\text {HWD }}$ \\
\cline { 2 - 4 } & $\mathbf{g ~ k g}^{-1}$ & \multicolumn{2}{|c|}{$\mathbf{m g ~ k g ~}^{-1}$} \\
\hline B0 & $15.2 \pm 1.11^{\mathrm{a}}$ & $1483 \pm 102^{\mathrm{a}}$ & $477 \pm 183^{\mathrm{a}}$ \\
\hline B10A & $14.5 \pm 0.70^{\mathrm{a}}$ & $1553 \pm 75^{\mathrm{ab}}$ & $494 \pm 287^{\mathrm{a}}$ \\
\hline B10B & $18.6 \pm 0.83^{\mathrm{b}}$ & $1573 \pm 51^{\mathrm{ab}}$ & $386 \pm 135^{\mathrm{a}}$ \\
\hline B20A & $17.9 \pm 1.73^{\mathrm{b}}$ & $1710 \pm 271^{\mathrm{b}}$ & $449 \pm 192^{\mathrm{a}}$ \\
\hline
\end{tabular}

Notes: $\mathrm{C}_{\text {org }}$ - soil organic carbon; $\mathrm{C}_{\mathrm{L}}$ - labile carbon; $\mathrm{C}_{\mathrm{HWD}}$ - hot-water extracted carbon. Different letters $(\mathrm{a}, \mathrm{b})$ between lines indicate that treatment means are significantly different at $p<0.05$ according to LSD test.

Table 2. Contents of $\mathrm{C}_{\mathrm{org}}, \mathrm{C}_{\mathrm{L}}$ and $\mathrm{C}_{\mathrm{HWD}}$ after the experiment - in all treatments after basal and N-, G- and NG-inducted respiration

\begin{tabular}{|l|c|c|c|}
\hline \multirow{2}{*}{ Soil in treatments after respiration } & $\mathbf{C}_{\text {org }}$ & $\mathbf{C}_{\mathrm{L}}$ & $\mathbf{C}_{\text {HWD }}$ \\
\cline { 2 - 4 } & $\mathbf{g ~ k g}^{-1}$ & \multicolumn{2}{|c|}{$\mathbf{m g ~ k g}^{-1}$} \\
\hline B & $15.9 \pm 1.39^{\mathrm{a}}$ & $1503 \pm 63^{\mathrm{a}}$ & $334 \pm 56^{\mathrm{a}}$ \\
\hline N & $16.2 \pm 1.00^{\mathrm{a}}$ & $1552 \pm 76^{\mathrm{a}}$ & $370 \pm 27^{\mathrm{a}}$ \\
\hline GG & $18.0 \pm 0.97^{\mathrm{b}}$ & $1704 \pm 102^{\mathrm{b}}$ & $729 \pm 119^{\mathrm{b}}$ \\
\hline
\end{tabular}

Notes: $\mathrm{C}_{\text {org }}$ - soil organic carbon; $\mathrm{C}_{\mathrm{L}}$ - labile carbon; $\mathrm{C}_{\mathrm{HWD}}$ - hot-water extracted carbon; $\mathrm{B}$ - basal respiration; $\mathrm{N}$ - nitrogen-inducted respiration; $\mathrm{G}$ - glucose inducted respiration; NG - together with nitrogen and glucose inducted respiration. Different letters (a, b) between lines indicate that treatment means are significantly different at $p<0.05$ according to LSD test.

Table 3. Correlation coefficients between $\mathrm{C}_{\text {org }}, \mathrm{C}_{\mathrm{L}}, \mathrm{C}_{\mathrm{HWD}}$ and cumulative $\mathrm{CO}_{2}$ emission

\begin{tabular}{|c|c|c|c|c|c|}
\hline & B0 & B10A & B10B & B20A & B20B \\
\hline \multicolumn{6}{|c|}{ Cumulative $\mathrm{CO}_{2}$ emission } \\
\hline $\mathrm{C}_{\text {org }}$ & $0.925^{* * *}$ & $0.833^{*}$ & $0.813^{*}$ & $0.966^{* * *}$ & 0.672 \\
\hline $\mathrm{C}_{\mathrm{L}}$ & $0.974^{* * *}$ & 0.504 & 0.541 & $0.861^{* *}$ & $0.757^{*}$ \\
\hline $\mathrm{C}_{\mathrm{HW}}$ & $0.837^{* *}$ & $0.914^{* *}$ & $0.868^{* *}$ & $0.903^{* *}$ & $0.901^{* *}$ \\
\hline
\end{tabular}

Notes: $\mathrm{C}_{\text {org }}-$ soil organic carbon; $\mathrm{C}_{\mathrm{L}}-$ labile carbon; $\mathrm{C}_{\mathrm{HWD}}-$ hot-water extracted carbon; ${ }^{\star} p<0.05 ;{ }^{\star *} p<0.01 ;{ }^{* * *} p<0.001$.

change significantly as a result of basal and $\mathrm{N}$ as well as the combination of NG-induced respiration, while potential respiration induced by easily degradable organic substrate $(G)$ significantly increased not only total $\mathrm{C}_{\text {org }}$ but also its labile forms - the most significant in case of $\mathrm{C}_{\mathrm{HWD}}$ (Table 2).

External factors such as temperature and soil moisture have a significant effect on $\mathrm{CO}_{2}$ emission (Lloyd et al., 2019), but in our case, these factors have been filtered out since our study was made in laboratory-controlled optimal conditions. Overall, there were observed significant correlations between $\mathrm{C}_{\mathrm{L}}(r=0.485$, $p<0.05), \mathrm{C}_{\mathrm{HWD}}(r=0.855, p<0.001)$ and cumulative $\mathrm{CO}_{2}$ emission. No correlation between $\mathrm{C}_{\text {org }}$ and cumulative $\mathrm{CO}_{2}$ emission was found. Increased porosity and higher SOM content have both been linked to higher gas diffusivity as mentioned by Li et al. (2002), Xu et al. (2008) and Novák et al. (2020) factors which may be responsible for higher cumulative $\mathrm{CO}_{2}$ emission from the soils into the atmosphere. If we evaluated correlations between $\mathrm{C}_{\text {org }}$ and its forms and cumulative $\mathrm{CO}_{2}$ emission individually - in all treatments - there were determined some differences related to biochar application (Table 3). Both biochar application rates and its re-application influenced correlations between $\mathrm{C}_{\text {org }}, \mathrm{C}_{\mathrm{L}}$,
$\mathrm{C}_{\mathrm{HWD}}$ and the cumulative $\mathrm{CO}_{2}$ emission. Clearly, higher $\mathrm{C}_{\mathrm{HWD}}$ content resulted in higher cumulative $\mathrm{CO}_{2}$ emission in all biochar treatments. This implies that the stability of $\mathrm{C}$ in biochar itself is fundamentally significant in terms of $\mathrm{CO}_{2}$ production.

\section{Conclusion}

Soil $\mathrm{C}$ sequestration and $\mathrm{CO}_{2}$ emission from agricultural soils can be managed by soil amendments as these impact soil organic matter decomposition. Our results show that biochar reduces $\mathrm{CO}_{2}$ emission driven by basal, N- and G-induced respiration. However, $\mathrm{CO}_{2}$ emission was increased by biochar when applied in combination with $\mathrm{N}$ - and G- additives. Extrapolating from our simple experiment, if a farmer were to apply biochar to the soil and add a source of easily degradable organic substances in combination with $\mathrm{N}$-fertilization, in the short term, this may result in an increase of $\mathrm{C}$ in the soil as well as in an increase of $\mathrm{CO}_{2}$ emission. Overall, we find that the application or re-application of biochar and its combinations only with $\mathrm{N}$ or easily degradable organic substances (no combination NG with biochar) significantly reduce the production of $\mathrm{CO}_{2}$ from agricultural soils. 


\section{References}

Alef, K. \& Nannipieri P. (1995). Methods in applied soil microbiology and biochemistry. London: Academic Press.

Asai, H., Samson, B.K., Stephan, H.M., Songyikhangsuthor, K., Homm, K., Kiyono, Y., Inoue, Y., Shiraiwa, T. \& Horie T. (2009). Biochar amendment techniques for upland rice production in northern Laos 1. Soil physical properties, leaf SPAD and grain yield. Field Crops Res., 111, 81-84. DOI: 10.1016/j.fcr.2008.10.008

Biswas, H., Prabhavathi, M., Patil, S.L., Kumar, A. \& Morade A.S. (2019) Application of biochar as soil amendment: Theory and practice. In A Rakshit, B. Sarkar \& P.Ch. Abhilash (Eds.), Soil amendments for sustainability, challenges and perspectives (pp. 159-174). Boca Raton, London, New York: CRC Press, Taylor \& Francis Group.

Duiker, S.W. \& Lal R. (1999). Crop residue and tillage effects on carbon sequestration in a Luvisol in central Ohio. Soil Tillage Res., 52, 73-81. DOI 10.1016/S0167-1987(99)00059-8.

Dziadowiec, H. \& Gonet S.S. (1999). Methodical guide-book for soil organic matter studies (in Polish). Warszawa: Prace komisji naukowych Polskiego towarystwa gleboznaczego.

Fischer, D. \& Glaser B. (2012). Synergisms between compost and biochar for sustainable soil amelioration. Rijeka: Tech Europe.

He, Y., Zhou, X., Jiang, L., Li, M., Du, Z., Zhou, G., Shao, J., Wang, X., Xu, Z., Hosseini Bai, S., Wallace, H. \& Xu C. (2017). Effects of biochar application on soil greenhouse gas fluxes: a meta-analysis. GCB Bioenergy, 9, 743-755. DOI: $10.1111 /$ gcbb.12376.

Horák, J., Kondrlová, E., Igaz, D., Šimanský, V., Felber, R., Lukac, M. Balashov, E.V, Buchkina, N.P., Rizhiya, E.Y. \& Jankowski M. (2017). Biochar and biochar with $\mathrm{N}$-fertilizer affect soil $\mathrm{N}_{2} \mathrm{O}$ emission in Haplic Luvisol. Biologia, 72(9), 995-1001. DOI: 0.1515/biolog-2017-0109.

Horák, J., Šimanský, V., Igaz, D., Juriga, M., Aydin, E. \& Lukac M. (2020) Biochar: An important component ameliorating the productivity of intensively used soils - review. Pol. J. Environ. Stud., 29(5), 1-7. DOI: $10.15244 /$ pjoes/113128.

Cheng, H., Hill, P.W., Bastami, M.S. \& Jones D.Y. (2016). Biochar stimulates the decomposition of simple organic matter and suppresses the decomposition of complex organic matter in a sandy loam soil. GCB Bioenergy, 9(6), 1110-1121. DOI: $10.1111 /$ gcbb.12402.

IPCC (2018): Summary for policymakers. In V. Masson-Delmotte, P. Zhai, H.O. Pörtner, D. Roberts, J. Skea, P.R. Shukla, A. Pirani, W. MoufoumaOkia, C. Péan, R. Pidcock, S. Connors, J.B.R. Matthews, Y. Chen, X. Zhou, M.I. Gomis, E. Lonnoy, T. Maycock, M. Tignor \& T. Waterfield (Eds.), Global warming of $1.5^{\circ} \mathrm{C}$. An IPCC Special Report on the impacts of global warming of $1.5^{\circ} \mathrm{C}$ above pre-industrial levels and related global greenhouse gas emission pathways, in the context of strengthening the global response to the threat of climate change, sustainable development, and efforts to eradicate poverty. Geneva: World Meteorological Organization. https://report.ipcc.ch/sr15/pdf/sr15 spm final.pdf

Ippolito, J.A., Spokas, K.A., Novak, J.M., Lentz, R.D. \& Cantrell K.B. (2015). Biochar elemental composition and factors influencing nutrient retention. In J. Lehmann \& J. Stephen (Eds.), Biochar for environmental management: Science, technology and implementation (pp. 137-161). London, UK, Boca Raton: Routledge, Taylor \& Francis Group.

Kasozi, G.N., Zimmerman, A.R., Nkedi-Kizza, P. \& Gao B. (2010). Catechol and humic acid sorption onto a range of laboratory-produced Black Carbons (Biochars). Environ. Sci. Technol., 44, 6189-6195. DOI: 10.1021/ es1014423.

Körschner, M., Schulz, E. \& Behm R. (1990). Heisswasserlőslicher C und N im Boden als Kriterium für das N-Nachliferungsvermőgen. Mikrobiologie, 145, 305-311.

Lang, R., Blagodatsky, S., Xu, J. \& Cadisch G. (2017). Seasonal differences in soil respiration and methane uptake in rubber plantation and rainforest. Agric. Ecosyst. Environ., 240, 314-328. DOI: 10.1016/j.agee.2017.02.032.
Li, X., Inubushi, K. \& Sakamoto K. (2002). Nitrous oxide concentrations in an Andisol profile and emissions to the atmosphere as influenced by the application of nitrogen fertilizers and manure. Biol. Fertil. Soils, 35, 108-113. DOI: 10.1007/s00374-002-0447-7.

Lloyd, K., Madramootoo, Ch.A., Edwards, K.P. \& Grant A. (2019). Greenhouse gas emissions from selected horticultural production systems in a cold temperate climate. Geoderma, 349, 45-55. DOI: 10.1016/j.geoderma.2019.04.030.

Loginow, W., Wisniewski, W., Gonet, S.S. \& Ciescinska B. (1987). Fractionation of organic carbon based on susceptibility to oxidation. Polish Journal of Soil Science, 20, 47-52.

Novák, J., Jankowski, K., Sosnowski, J., Malinowska, E. \& WiśniewskaKadżajan B. (2020). Influence of plant species and grasslands quality on sequestration of soil organic carbon. Ekológia (Bratislava), 39(3), 289300. DOI: 10.2478/eko-2020-0023.

Popelárová, E., Voříšek, K. \& Strnadová S. (2002). Mineralization activity in soils for the development of the precision farming system. Arch. Acker Pfl. Boden, 48, 147-153.

Rizhiya, E.Y., Horák, J., Šimanský, V. \& Buchkina N.P. (2020). Nitrogen enriched biochar-compost mixture as a soil amendment to the Haplic Luvisol: effect on greenhouse gas emission. Biologia, 75, 873-884. DOI: 10.2478/s11756-019-00335-7.

Schlesinger, W.H. \& Andrews J.A. (2000). Soil respiration and the global carbon cycle. Biogeochemistry, 48, 7-20. DOI: 10.1023/A:1006247623877.

Schulz, H. \& Glaser B. (2012). Effects of biochar compared to organic and inorganic fertilizers on soil quality and plant growth in a greenhouse experiment. J. Soil Sci. Plant Nutr., 175, 410-422. DOI: 10.1002/ jpln.201100143.

Smith, P., Bustamante, M., Ahammad, H., Clark, H., Dong, H., Elsiddig, E.A., Haberl, H., Harper, R., House, J., Jafari, M., Masera, O., Mbow, C., Ravindranath, N.H., Rice, C.W., Robledo Abad, C., Romanovskaya, A., Sperling, F. \& Tubiello F. (2014). Agriculture, forestry and other land use (AFOLU). In O. Edenhofer, R. Pichs-Madruga, Y. Sokona, E. Farahani, S. Kadner, K. Seyboth, A. Adler, I. Baum, S. Brunner, P. Eickemeier, B. Kriemann, J. Savolainen, S. Schlömer, C. von Stechow, T. Zwickel \& J.C. Minx (Eds.), Climate Change 2014: Mitigation of Climate Change. Contribution of Working Group III to the Fifth Assessment Report of the Intergovernmental Panel on Climate Change (pp. 811-922). Cambridge, New York: Cambridge University Press.

Šikanja, S. \& Milovanović N. (2020). The impact of climate change on the appearance of some pathogens in oak forests (Quercus frainetto Ten.) and the analysis of thickness increase in the Šmadija Region (Central Serbia). Ekológia (Bratislava), 39(4), 310-321. DOI: 10.2478/eko-20200025 .

Šimanský, V., Horák, J., Igaz, D., Jonczak, J., Markiewicz, M., Felber, R., Rizhiya, E.Y. \& Lukac M. (2016). How dose of biochar and biochar with nitrogen can improve the parameters of soil organic matter and soil structure? Biologia, 71(9), 989-995. DOI: 10.1515/biolog-2016-0122.

Wang, Z., Zong, H., Zheng, H., Liu, G., Chen, L. \& Xing B. (2015). Reduced nitrification and abundance of ammonia-oxidizing bacteria in acidic soil amended with biochar. Chemosphere, 138, 576-583. DOI: 10.1016/j.chemosphere.2015.06.084.

Whitman, T., Singh, B.P. \& Zimmerman A. (2015). Priming effects in biocharamended soils: Implications of biochar-soil organic matter interactions for carbon storage. In J. Lehmann \& J. Stephen (Eds.), Biochar for environmental management: Science, technology and implementation (pp. 455-487). London, Boca Raton: Routledge, Taylor \& Francis Group.

Xu, X., Tian, H. \& Hui D. (2008). Convergence in the relationship of CO2 and $\mathrm{N} 2 \mathrm{O}$ exchanges between soil and atmosphere within terrestrial ecosystems. Glob. Chang. Biol., 14, 1651-1660. DOI: 10.1111/j.1365 2486.2008.01595.x. 